\title{
Application Volumes and Sizes of Droplets for the Application OF DIQUAT HERBICIDE IN THE CONTROL OF Eichhornia crassipes ${ }^{1}$
}

\author{
Volumes de Aplicação e Tamanhos de Gotas para Aplicação do Herbicida Diquat no Controle de \\ Eichhornia crassipes
}

ALMEIDA, D.P. ${ }^{2}$, AGOSTINI, A.R. ${ }^{2}$, YAMAUCHI, A.K. ${ }^{2}$, DECARO JR., S.T. ${ }^{2}$, and FERREIRA, M.C. ${ }^{2}$

\begin{abstract}
The objective of this study was to evaluate the efficiency of application and the efficacy of control of water hyacinth (Eichhornia crassipes) with the use of the diquat herbicide done with two application volumes associated to three droplets classes. Three experiments were conducted; in the first, the application efficiency was evaluated; in the second, the control efficiency and; in the third, the droplet spectrum. They were conducted in a completely randomized design with five, four and six replicates, respectively. The treatments were arranged in a $2 \times 3$ factorial design, with two application volumes (100 and $\left.200 \mathrm{~L} \mathrm{ha}^{-1}\right)$ and three droplets classes (fine, extremely coarse and ultra-coarse) to the first and second experiment and the third comprised two diquat concentrations in spray solution $(2$ and $4 \mathrm{~g}$ i.a. $\mathrm{L}^{-1}$ ) and three droplets classes (fine, extremely coarse and ultra-coarse). The application efficiency was determined by the coverage by droplets, spray deposition and active ingredient of the herbicide (diquat). The efficacy was measured by the control and the percentage of plants with regrowth at 50 days after application. The spectrum of droplets produced per each nozzle model used to obtain the droplets classes were analyzed. According to the parameters analyzed, using the droplets classes extremely thick and ultra thick can provide greater certainty in the application of diquat in the aquatic environment associated with the deposition of the active and sufficient coverage to control Eichhornia crassipes with both application volumes
\end{abstract}

Keywords: spray volume, volume median diameter, chemical control of aquatic plants.

\begin{abstract}
RESUMO - Objetivou-se neste estudo avaliar a eficiência da aplicação e eficácia de controle de aguapé (Eichhornia crassipes) com o uso do herbicida diquat veiculado com dois volumes de aplicação. associado a três classes de gotas. Foram conduzidos três experimentos: no primeiro avaliou-se a eficiência da aplicação; no segundo, a eficácia de controle; e, no terceiro, o espectro de gotas, conduzidos em delineamento inteiramente casualizado, com cinco, quatro e seis repetições, respectivamente. Os tratamentos foram dispostos em esquema fatorial $2 \times 3$, com dois volumes de aplicação (100 e $200 \mathrm{~L} \mathrm{ha}^{-1}$ ) e três classes de gotas (fina, extremamente grossa e ultragrossa) para o primeiro e o segundo experimento, e o terceiro foi constituído por duas concentrações do herbicida diquat na calda (2 e $4 \mathrm{~g}$ de i.a. $\mathrm{L}^{-1}$ ) e por três classes de gotas (fina, extremamente grossa e ultragrossa). A eficiência da aplicação foi determinada pela cobertura por gotas, deposição de calda e ingrediente ativo do herbicida (diquat). Já a eficácia foi quantificada pelo controle e pela porcentagem de plantas com rebrote até 50 dias após a aplicação. Foi analisado o espectro das gotas produzidas por cada modelo de pontas utilizado para obter as classes de gotas. De acordo com os parâmetros analisados, o uso das classes de gotas extremamente grossa e ultragrossa pode proporcionar maior segurança na aplicação do herbicida diquat em ambiente aquático, associado à deposição do ativo e cobertura suficiente para controle de E. crassipes com ambos os volumes de aplicação.
\end{abstract}

Palavras-chave: volume de calda, diâmetro mediano volumétrico, controle químico de plantas aquáticas.

Recebido para publicação em 22.6.2015 e aprovado em 7.12.2015.

Universidade Estadual Paulista, Jaboticabal campus, São Paulo-SP, BraZil, <dieimissonpa@gmail.com>. 


\section{INTRODUCTION}

Macrophytes are important in the operation of the ecosystems in which they occur, being capable of establishing a strong connection between the aquatic and terrestrial environment that surrounds them. Among their functions, one can mention the elimination of the excess of toxic and eutrophying substances from the water by retaining the material carried by erosion of terrestrial environments and the promotion of spatial and temporal heterogeneity, which contributes to a greater system diversity (Pitelli et al., 2008; Souza, 2013).

Considering only the aquatic environment, there are several examples of macrophytes that were introduced into new places. A classic example of that is the water hyacinth (Eichhornia crassipes), a tropical America native plant that was introduced into several countries as an ornamental plant (Holm et al., 1977). In the new environments, the absence of the powerful natural enemies and the characteristics of water and the water bodies provide favorable conditions so that the water hyacinth would form great population densities (Olaleye et al., 1993).

According to Pitelli et al. (2008), the chemical control of aquatic plants is restricted to a few herbicides due to the restrictions imposed by the legislation to the environmental impact, to the market size and to the private sector, as well as to the application technology. The environmental restrictions are the most important factors because the waterways are used for several purposes such as source of water for human and animal consumption, irrigation of crops, leisure, navigation and generation of hydropower.

According to data from the World Bank, in 1990, E. crassipes already caused economic losses of around US\$ 500 million dollars a year (Olaleye \& Akinyemiju, 1996). Thus, the chemical control by herbicides is one of the alternatives for the handling of this macrophyte. However, it is still scarce to find information and even researches which aim to generate information on the efficiency and the application techniques of the herbicide products in aquatic environments.
In a terrestrial environment, spraying of herbicides into water is the most used means for taking and distributing the products to the plants that will be controlled. The applications are normally done with sprayers equipped with hydropower nozzles, in which the combination of the size of droplets produced by the spray nozzles, the application volume $\left(\mathrm{L} \mathrm{ha}^{-1}\right)$ and the meteorological conditions can influence the quality of distribution, the deposition, and, consequently, the efficacy of the products (Bracamonte et al., 1999; Garcia et al., 2004; Rodrigues et al., 2011; Timossi et al., 2013; Almeida et al., 2014, 2015).

The diquat herbicide has been studied as to the efficacy in aquatic plants and, because it has low translocation in plants, it is commonly applied with high spray volumes, associated to different droplets classes (Pitelli et al., 2008, 2011; Martins et al., 2011). However, there is demand for the reduction of costs, and one of the alternatives is to increase the operational efficiency of the pesticides spray through new techniques, such as the use of reduced volumes associated to the spectrum of droplets with a smaller potential of loss through drifting.

The possibility of release of certain herbicide molecules for the application in aquatic systems in Brazil will generate demand for information on the application of scientifically validated techniques, in order to minimize the risks of environmental contamination. Therefore, the present study aimed at evaluating the efficiency of the application and the efficacy of water hyacinth control (E. crassipes) with the use of diquat with two volumes of application associated to three droplets classes.

\section{MATERIAL AND METHODS}

The experiment was conducted in 2014 . There were experiments in a greenhouse and in laboratories. Studies in greenhouse were conducted in the Núcleo de Estudos e Pesquisa Ambientais em Matologia - NEPEAM. In the laboratory, studies were conducted in the Núcleo de Estudo e Desenvolvimento em Tecnologia de Aplicação - NEDTA of Universidade Estadual Paulista, Campus in Jaboticabal. 


\section{Tests in greenhouse}

There were two tests - in one of them, the evaluation was on the efficiency of the application and, on the other, the efficacy of control - conducted in an entirely randomized design with five and four repetitions, respectively. The treatments (Table 1) were disposed in a $2 \times 3$ factorial scheme. The interaction factors were composed of application volume (100 and $200 \mathrm{~L} \mathrm{ha}^{-1}$ ) and droplets classes (fine, extremely coarse and ultra coarse), established according to the volume median diameter (VMD), according to ASABE (2009). Each experimental unit was composed of a box with water hyacinth in full vegetative development.

On Table 1, there is also the real volume median diameter (VMD) of the sprayed droplets for the three models (TT 110015 and AI 110015 and TTI110015), with the herbicide in two spray concentrations, 2 and $4 \mathrm{~g}$ i.a. $\mathrm{L}^{-1}$, when spraying 200 and $100 \mathrm{~L} \mathrm{ha}^{-1}$, respectively. The VMD was determined by laser diffraction, through a particles size analyzer (Mastersizer, Malvern Instruments Limited).

The Eichhornia crassipes were grown in boxes of $2 \mathrm{dm}^{3}(0.15 \times 0.15 \times 0.11 \mathrm{~m})$ with water, in a greenhouse, for a period of 30 days. Sprouts of water hyacinth were used in the plantation, newly detached from the parent plant and containing 3-4 leaves. Before planting, the boxes were lined with a layer of $5 \mathrm{~cm}$ of dirt and sand in the proportion of $2: 1$, and then they were filled with water up to $1 \mathrm{~cm}$ of the surface, leaving a layer of $10 \mathrm{~cm}$ of water on the sediment; later on, the boxes were incubated for a period of 15 days, before the plantation of water hyacinth (Pitelli et al., 2011).

The herbicide was applied in the second half of September 2014. Diquat (Reglone, 200 g i.a. L ${ }^{-1}$, CS, Syngenta) was used in the dosage of $0.4 \mathrm{~kg} \mathrm{ha}^{-1}$ of active ingredient in both application volumes: 200 and $100 \mathrm{~L} \mathrm{ha}^{-1}$.

In the application of herbicides, a research sprayer was used, kept at a constant pressure by $\mathrm{CO}_{2}$. The spray bar was equipped with two spaced nozzles of $0.5 \mathrm{~m}$ between each other. The working pressure on the nozzles was constant $(300 \mathrm{kPa})$, that is, the flow rate in $\mathrm{L}$ min $^{-1}$ was constant so that, when spraying both application volumes, only the sprayer displacement speed was altered.

The atmosphere conditions regarding the application were monitored through an Instrutherm digital term hygro anemometer. The application was done between 10:30 a.m. and 12:45 p.m., under the average air temperature of $28.3^{\circ} \mathrm{C}$, air relative humidity of $58.6 \%$, cloud coverage of $80 \%$ and winds between 1.6 and $3.1 \mathrm{~km} \mathrm{~h}^{-1}$.

\section{Evaluations of the application efficiency}

The application quality, considering density of droplets and coverage percentage,

Table 1 - Treatments used in the application of the diquat herbicide to prove the efficiency of the application and control of the water hyacinth, average volume diameter and used nozzle models

\begin{tabular}{|c|c|c|c|c|}
\hline \multirow{2}{*}{ Treatment } & $\begin{array}{c}\text { Application } \\
\text { volume }\end{array}$ & Droplets class* & VMD & Spray nozzles models** \\
\cline { 2 - 4 } & $\left(\mathrm{L} \mathrm{ha}^{-1}\right)$ & & 166 & TT 11015 \\
\hline 1 & 200 & Fine & 190 & TT 11015 \\
\hline 2 & 100 & Fine & 599 & AI 11015 \\
\hline 3 & 200 & Extremely coarse & 590 & AI 11015 \\
\hline 4 & 100 & Extremely coarse & 734 & TTI 11015 \\
\hline 5 & 200 & Ultra coarse & 705 & TTI 11015 \\
\hline 6 & 100 & Ultra coarse & \\
\hline
\end{tabular}

* Droplets class according to the classification of the ASAE S572.1 standard, in which Fine (VMD 106-235 $\mu$ m), Extremely coarse (VMD 503-665 $\mu \mathrm{m}$ ) and Ultra coarse (VMD>665) Droplets.** Nozzle Spraying Models under working pressure of $300 \mathrm{kPa}$, for the establishment of droplets classes. 
was registered with the help of water sensitive paper produced by Spraying Systems Co. In E. crassipes, water sensitive papers were fixed in the upper third of the five plants that composed the repetitions of each treatment.

After spraying, the water sensitive papers were collected, coded and packaged in plastic bags, in order to avoid contamination by the air humidity. Later on, for the analysis of the percentage of coverage by droplets and density of droplets, the water sensitive papers were digitalized with the help of a scanner with a 600 dpi resolution. The files obtained were analyzed by the Gotas ${ }^{\circledR}$ software.

In order to check the spray deposition on the water hyacinth plants, a metallic marker was added to the sprays, having manganese sulfate as its basis $\left(31 \% \mathrm{Mn}^{2+}\right)$ in the concentration of $10 \mathrm{~g} \mathrm{~L}^{-1}$ of spray. After 60 minutes of spray application, the plants were collected and stored in properly identified plastic bags for later extraction of the marker.

The extraction of the marker was done according to the methodology described by Oliveira \& Machado-Neto (2003). The samples (treated plants) were put in plastic bags containing $100 \mathrm{~mL}$ of the $\mathrm{HCl} 0.2 \mathrm{~N}$ solution, where they were at rest for 60 minutes so that there would be dissolution of the applied salts. After the extraction, the extract was filtered in order to quantify the recovered metal ion $\left(\mathrm{Mn}^{2+}\right)$.

The quantification was done in an atomic absorption spectrophotometer. Therefore, the mass of the marker retained in the target was determined from the initial concentration of the spray and the volume of samples dilution. For the deposit in the E. crassipes plants, the total deposit was divided by the leaf area and the bulb area of plants, obtaining the estimates in $\mu \mathrm{L} \mathrm{cm}^{-2}$ of leaf and spray bulb and deposited active ingredient.

\section{Evaluations of the efficacy of the herbicide}

At 3, 7, 14, 21 and 28 days after application (DAA) of the herbicide, visual evaluations of the control percentage for E. crassipes were done, based on the visual estimate of the percentage of necrotic and dead plant material above the water blade (SBCPD, 2000; Pitelli et al., 2011). These estimates were always done by more than one person, and the average of the evaluators was used as a final value in each parcel (Pitelli et al., 2011). At 50 DAA, there was regrowth in the plants treated with the herbicide.

\section{Tests in laboratory}

The spectrum of sprayed droplets was analyzed by the three models presented on Table 1 in the Laboratory of Particles Analyses (LAPAR).

The test was done in a completely randomized design with six repetitions. The treatments were disposed in a $2 \times 3$ factorial scheme. The interaction factors were composed of two concentrations of the diquat herbicide in the spray ( 2 and $4 \mathrm{~g}$ of i.a. $\mathrm{L}^{-1}$ ) and of the droplets classes (fine, extremely coarse and ultra coarse).

The analyzed parameters were the uniformity coefficient (equation 1) of sprayed droplets and the percentage of volume in droplets with diameters smaller than $100 \mu \mathrm{m}$.

The uniformity coefficient (Coef.) was determined by equation 1 :

$$
\text { Coef. }=\frac{\text { Dv } 0.9-\text { Dv } 0.1}{\text { Dv } 0.5}
$$

In which Dv0.1 and Dv0.9 refer to the droplet diameter, such that 10 and $90 \%$, respectively, of the sprinkled volume is composed by droplets of a smaller diameter.

The diameter of the droplets was determined by laser diffraction during the passage of the sprayed droplets through the sample region of a particles size analyzer (Mastersizer, Malvern Instruments Limited), adjusted to evaluate droplets of up to 3,000 $\mu \mathrm{m}$. The diffraction degree that the light beam suffers is inversely proportional to the particle size (Fernandes et al., 2007). The data codification, according to the algorithm elaborated for the characterization of the droplets diameter per laser diffraction was processed and put in a table directly through the Mastersizers ${ }^{\circledR}$ program, version 2.19. 
The spray nozzles were installed in a radial conveyor positioned at $40 \mathrm{~cm}$ of the laser beam, according to the FAO standards (1998).

\section{Statistical analyses}

The data was submitted to a variance analysis at 5\% significance, and the averages, when pertinent, were compared by the Tukey test at a level of $\mathrm{p} \leq 0.05$ significance.

\section{RESULTS AND DISCUSSION}

On Table 2, it is seen that there was significant interaction among the studied factors - application volume (AV) and droplets class (DC) - for the variables density of droplets and percentage of coverage.

Table 2 - Values of F and variation coefficients ( $\mathrm{VC} \%$ ), applied to the averages of droplets density (droplets $\mathrm{cm}^{-2}$ ) and the percentage of coverage by droplets

\begin{tabular}{|c|l|c|c|}
\hline & \multicolumn{1}{|c|}{ Variables } & $\begin{array}{c}\text { Density } \\
\left(\text { droplets cm }^{-2}\right)\end{array}$ & $\begin{array}{c}\text { Coverage } \\
(\%)\end{array}$ \\
\hline \multirow{3}{*}{$\mathrm{F}$} & Application Volume (AV) & $37.43^{*}$ & $25.91^{*}$ \\
\cline { 2 - 4 } & Droplets Class (DC) & $85.16^{*}$ & $79.80^{*}$ \\
\cline { 2 - 4 } & AV x DC & $15.38^{*}$ & $18.23^{*}$ \\
\hline- & 24.49 & 25.30 \\
\hline
\end{tabular}

* Significant at $5 \%$ significance; ${ }^{\text {ns }}$ non significant at $5 \%$ significance.
The AV of $100 \mathrm{~L} \mathrm{ha}^{-1}$ (Table 3) provided smaller density of droplets only in fine DC. However, this application volume $\left(100 \mathrm{~L} \mathrm{ha}^{-1}\right)$ reduced the percentage of coverage of the target in all droplets classes studied. However, it is shown that, even though there is no significant reduction of the droplets density values, the coverage is influenced by the application volume; yet, this reduction is not proportional to the decrease in spray volume when using extremely coarse and ultra coarse droplets.

Also on Table 3 , when analyzing the droplets classes in each application volume, it is seen that the fine DC in the spray volume of $200 \mathrm{~L} \mathrm{ha}^{-1}$ provided greater density of droplets and percentage of coverage when compared to the extremely coarse and ultra coarse droplet. In the volume of $100 \mathrm{~L} \mathrm{ha}^{-1}$, the fine DC did not differ from the extremely coarse one in the two analyzed variables (density and coverage); therefore, in this volume, the ultra coarse DC provided smaller density and droplets coverage. Theoretically, smaller droplets, when captured by the target, can provide better coverage and, consequently, better results (Matuo, 1990); however, the spectrum of the fine droplet class has greater potential for risk of loss through drifting (Table 7).

Table 3 - Unfolding of the significant interaction for density of droplets (droplets $\mathrm{cm}^{-2}$ ) and droplets coverage percentage, according to the volumes of application and the droplets classes

\begin{tabular}{|c|c|c|c|}
\hline \multicolumn{4}{|c|}{ Density of droplets (droplets $\mathrm{cm}^{-2}$ ) } \\
\hline \multirow{2}{*}{ Application Volume $\mathrm{L} \mathrm{ha}^{-1}(\mathrm{AV})$} & \multicolumn{3}{|c|}{ Droplets class $^{\underline{1 /}}(\mathrm{DC})$} \\
\hline & Fine & Extremely coarse & Ultra coarse \\
\hline $200^{2 /}$ & $168.85 \mathrm{aA}$ & $61.69 \mathrm{bA}$ & $35.9 \mathrm{bA}$ \\
\hline 100 & $81.80 \mathrm{aB}$ & $47.81 \mathrm{bA}$ & $22.3 \mathrm{bA}$ \\
\hline \multirow{2}{*}{ DMS } & \multicolumn{2}{|c|}{ AV inside DC } & DC inside $\mathrm{AV}$ \\
\hline & \multicolumn{2}{|c|}{22.29} & 26.98 \\
\hline \multicolumn{4}{|c|}{ Coverage by droplets $(\%)$} \\
\hline $200^{2 /}$ & $31.60 \mathrm{aA}$ & $25.22 \mathrm{bA}$ & $20.99 \mathrm{bA}$ \\
\hline 100 & $15.39 \mathrm{aB}$ & $16.13 \mathrm{aB}$ & $8.78 \mathrm{bB}$ \\
\hline \multirow{2}{*}{ DMS } & \multicolumn{2}{|c|}{ AV inside DC } & $\mathrm{DC}$ inside $\mathrm{AV}$ \\
\hline & \multicolumn{2}{|c|}{3.76} & 55 \\
\hline
\end{tabular}

* Averages in the same line, followed by equal lower case letters and, in the same column, followed by equal upper case letters, do not differ from each other by the Tukey test $(\mathrm{p} \leq 0,05) .{ }^{1 /}$ Classes of droplets established by the nozzle models TT 11015 , AI 11015 , TTI 11015 .

2/ Diquat (Reglone ${ }^{\circledR}, 200 \mathrm{~g}$ i.a. $\mathrm{L}^{-1}, \mathrm{CS}$, Syngenta) in the dosage of $0.4 \mathrm{~kg} \mathrm{ha}^{-1}$ of active ingredient, that is, herbicide concentrations of 2 and $4 \mathrm{~g}$ of i.a. $\mathrm{L}^{-1}$ for the respective volumes of 200 and $100 \mathrm{~L} \mathrm{ha}^{-1}$. 
According to Christofoletti (1997), when applying low translocation herbicides in postemergence plants, it is required to obtain from 30 to 40 droplets $\mathrm{cm}^{-2}$ at the target. However, as presented and discussed previously, regarding the application of diquat in E. crassipes, it is evident that the droplets with higher VMD can result in coverage (Table 3) and deposition of enough product in the target surface (Table 4) for the efficient control (Table 5) and with a smaller potential risk for loss (Tables 6 and 7).
The spray volumes influenced in the deposition of the herbicide, such that $200 \mathrm{~L} \mathrm{ha}^{-1}$ provided a greater spray deposit and $100 \mathrm{~L} \mathrm{ha}^{-1}$, greater deposit of active ingredient (Table 4). Therefore, it is seen that, even with a smaller spray deposition, the AV of $100 \mathrm{~L} \mathrm{ha}^{-1}$ provided a higher amount of active ingredient of the herbicide deposited in the water hyacinth plants. It is worth highlighting that the increase in the deposit of active ingredient in the plants of E. crassipes occurred due to the increase in the concentration of the

Table 4 - Values of F and variation coefficients (VC\%), applied to the averages of spray deposition and active ingredient of diquat in water hyacinth (Eichhornia crassipes)

\begin{tabular}{|c|c|c|c|}
\hline & Variables & $\begin{array}{c}\text { Deposition } \\
\left(\mu \mathrm{L} \text { of spray } \mathrm{cm}^{-2}\right)\end{array}$ & $\begin{array}{c}\text { Deposition } \\
\left(\mu \mathrm{g} \text { of i.a. } \mathrm{cm}^{-2}\right)\end{array}$ \\
\hline \multirow{3}{*}{$\mathrm{F}$} & Application Volume (AV) & $59.68 *$ & $13.86^{*}$ \\
\hline & Droplets Class (DC) & $0.76^{\mathrm{ns}}$ & $0.360^{\mathrm{ns}}$ \\
\hline & AV $x$ DC & $0.32^{\mathrm{ns}}$ & $0.06^{\mathrm{ns}}$ \\
\hline \multirow{2}{*}{$\mathrm{AV}^{1 /}$} & $200 \mathrm{~L} \mathrm{ha}^{-1}$ & $0.39 \mathrm{a}$ & $0.77 \mathrm{~b}$ \\
\hline & $100 \mathrm{~L} \mathrm{ha}^{-1}$ & $0.25 \mathrm{~b}$ & $1.01 \mathrm{a}$ \\
\hline \multicolumn{2}{|r|}{ DMS } & 0.0358 & 0.197 \\
\hline \multirow{3}{*}{$\mathrm{DC}^{2 /}$} & Fine & 0.33 & 0.91 \\
\hline & Extremely coarse & 0.32 & 0.90 \\
\hline & Ultra coarse & 0.31 & 0.85 \\
\hline \multicolumn{2}{|r|}{$\mathrm{CV}(\%)$} & 15 & 20 \\
\hline
\end{tabular}

* Significant at $5 \%$ significance; ${ }^{\text {ns }}$ Non significant at 5\% significance. ${ }^{1 / D i q u a t}$ (Reglone, $200 \mathrm{~g}$ i.a. $\mathrm{L}^{-1}$, CS, Syngenta) in the dosage of $0.4 \mathrm{~kg} \mathrm{ha}^{-1}$ of active ingredient. $\stackrel{2}{2}$ Droplets classes established by the nozzle models TT 11015, AI 11015, and TTI 11015, operating under a pressure of $300 \mathrm{kPa}$.

Table 5 - Values of F and variation coefficient (VC\%), applied to the averages of control percentages at 3, 7, 14, 21 and 28 days after application (DAA) of the diquat herbicide in water hyacinth (Eichhornia crassipes)

\begin{tabular}{|c|c|c|c|c|c|c|}
\hline & \multirow{2}{*}{ Variables } & \multicolumn{5}{|c|}{ Control (\%) } \\
\hline & & 3DAA & $7 \mathrm{DAA}$ & $14 \mathrm{DAA}$ & $21 \mathrm{DAA}$ & $28 \mathrm{DAA}$ \\
\hline \multirow{3}{*}{$\mathrm{F}$} & Application Volume (AV) & $1.64^{\mathrm{ns}}$ & $5.44^{\mathrm{ns}}$ & $1.20^{\mathrm{ns}}$ & $0.36^{\mathrm{ns}}$ & $0.24^{\mathrm{ns}}$ \\
\hline & Droplets Class (DC) & $0.55^{\mathrm{ns}}$ & $0.33^{\mathrm{ns}}$ & $1.20^{\mathrm{ns}}$ & $0.16^{\mathrm{ns}}$ & $0.14^{\mathrm{ns}}$ \\
\hline & $\mathrm{AV} \times \mathrm{DC}$ & $0.55^{\mathrm{ns}}$ & $0.77^{\mathrm{ns}}$ & $1.20^{\mathrm{ns}}$ & $0.48^{\mathrm{ns}}$ & $1.50^{\mathrm{ns}}$ \\
\hline \multirow{2}{*}{$\mathrm{AV}^{\underline{1}}$} & $200 \mathrm{~L} \mathrm{ha}^{-1}$ & 43.8 & $63.3 \mathrm{a}$ & 94.58 & 95.67 & 98.83 \\
\hline & $100 \mathrm{~L} \mathrm{ha}^{-1}$ & 41.3 & $60.4 \mathrm{~b}$ & 93.75 & 96.16 & 99.00 \\
\hline \multicolumn{2}{|r|}{ DMS } & & 2.6 & & & \\
\hline \multirow{3}{*}{$\mathrm{DC}^{2 /}$} & Fine $^{2 /}$ & 42.5 & 61.3 & 93.8 & 96.25 & 99.12 \\
\hline & \begin{tabular}{|l|} 
Extremely coarse \\
\end{tabular} & 43.8 & 62.5 & 95.0 & 95.75 & 98.75 \\
\hline & Ultra coarse & 41.3 & 61.9 & 93.8 & 95.75 & 98.87 \\
\hline \multicolumn{2}{|r|}{$\mathrm{CV}(\%)$} & 11.26 & 4.95 & 1.98 & 2.13 & 1.10 \\
\hline
\end{tabular}

* Significant at $5 \%$ significance; ns Non significant at 5\% significance. ${ }^{1 /}$ Diquat (Reglone, $200 \mathrm{~g}$ i.a. L ${ }^{-1}$, CS, Syngenta) in the dosage of $0.4 \mathrm{~kg} \mathrm{ha}^{-1}$ of active ingredient. $\stackrel{2}{ }$ Droplets classes established by the nozzle models TT 11015, AI 11015, and TTI 11015, operating under a pressure of $300 \mathrm{kPa}$. 
Table 6 - Values of F and variation coefficients (VC\%), applied to the average of the variables, uniformity coefficient and percentage of the volume of droplets smaller than $100 \mu \mathrm{m}$

\begin{tabular}{|c|c|c|c|}
\hline & Variables & Uniformity coefficient & $\begin{array}{c}\% \text { Volume of droplets }<100 \\
(\mu \mathrm{m})\end{array}$ \\
\hline \multirow{3}{*}{$\mathrm{F}$} & Concentration of the herbicide ([ ] Herbicide) & $0.049^{\mathrm{ns}}$ & $5.5^{*}$ \\
\hline & Droplets Class (DC) & $31.282 *$ & $614.5^{*}$ \\
\hline & [] Herbicide x DC & $0.442^{\mathrm{ns}}$ & $6.8 *$ \\
\hline \multirow{2}{*}{ AV } & $200 \mathrm{~L} \mathrm{ha}^{-1}$ & 1.67 & \\
\hline & $100 \mathrm{~L} \mathrm{ha}^{-1}$ & 1.67 & \\
\hline \multirow{3}{*}{$\mathrm{DC}$} & Fine & $1.96 \mathrm{a}$ & \\
\hline & Extremely coarse & $1.66 \mathrm{~b}$ & \\
\hline & Ultra coarse & $1.40 \mathrm{c}$ & \\
\hline \multicolumn{4}{|c|}{ DMS } \\
\hline & $\mathrm{CV}(\%)$ & 10.33 & 17.67 \\
\hline
\end{tabular}

* Significant at $5 \%$ significance; ns Non significant at $5 \%$ significance.

Table 7 - Unfolding of the significant interaction for the percentage of the volume of smaller droplets $100 \mu \mathrm{m}$, according to the concentrations of herbicide in the spray and the droplets classes

\begin{tabular}{|c|c|c|c|c|}
\hline \multirow{2}{*}{$\begin{array}{c}\text { Concentration of the Herbicide g of i.a. } \mathrm{L}^{-1} \\
\text { ([ ] Herbicide) }\end{array}$} & \multicolumn{4}{|c|}{ Droplets Class $^{\underline{1}}$ (DC) } \\
\hline & Fine & \multicolumn{2}{|c|}{ Extremely coarse } & Ultra coarse \\
\hline 2 & $20.78 \mathrm{Aa}$ & \multicolumn{2}{|c|}{$2.89 \mathrm{Ab}$} & $1.25 \mathrm{Ab}$ \\
\hline 4 & $17.34 \mathrm{Ba}$ & \multicolumn{2}{|c|}{$3.33 \mathrm{Ab}$} & $1.02 \mathrm{Ac}$ \\
\hline \multirow{2}{*}{ DMS } & \multicolumn{2}{|c|}{ [ ] Herbicide inside the DC } & \multicolumn{2}{|c|}{ DC inside the [ ] Herbicide } \\
\hline & \multicolumn{2}{|c|}{1.62} & \multicolumn{2}{|c|}{1.95} \\
\hline
\end{tabular}

* Averages in the same line, followed by equal lower case letters and, in the same column, followed by equal upper case letters, do not differ from each other by the Tukey test $(\mathrm{p} \leq 0.05)$. 1/ Droplets classes established by the nozzle models TT 11015 , AI 11015 , TTI 11015 . 2/ Diquat (Reglone ${ }^{\circledR}$ ) in the dosage of $0.400 \mathrm{~kg} \mathrm{ha}^{-1}$ of active ingredient, therefore herbicide concentrations of 2 and $4 \mathrm{~g}^{\text {i.a. } \mathrm{L}^{-1}}$ in the application of the respective volumes of 200 and $100 \mathrm{~L} \mathrm{ha}^{-1}$.

herbicide in the reduced volume applications (100 $\left.\mathrm{L} \mathrm{ha}^{-1}\right)$, associated to the possible nonoccurrence of the displacement speed and/or wind, seeing that the plants density (plants $\mathrm{m}^{-2}$ ) was the same for the application in both spray volumes (Tomazela et al., 2006).

The application of spray volume of $100 \mathrm{~L} \mathrm{ha}^{-1}$ was done with the same working pressure in the nozzles used to establish the droplets classes, in relation to $200 \mathrm{~L} \mathrm{ha}^{-1}$, but with twice the displacement speed of the sprayer. This offers the possibility of increasing the operational performance, both through the increase of speed and through the reduction of stops to refuel the sprayer, and to obtain operational and application efficiency (coverage and deposition at the target) (Table 4). In cases where it is not possible to increase the speed and you wish to reduce the application volume, you can use nozzles with smaller flow rates or increase the spacing between the nozzles; therefore, the increase in the operational performance will be conditioned to the reduction of stops for refuel of the sprayer (Bauer et al., 2006; Ferreira et al., 2011; Volpe et al., 2012).

In the evaluations of control efficacy (Table 5), it was seen at 7 DAA that the volume of $200 \mathrm{~L} \mathrm{ha}^{-1}$ provided control of $63.3 \%$, a significant increase of $2.9 \%$ in relation to the AV of $100 \mathrm{~L} \mathrm{ha}^{-1}$, showing an increase in the desiccation speed (control) of the E. crassipes plants. According to Pitelli et al. (2011), the fast action can produce great amount of material subject to decomposition in a short period of time, and it can induce the biological demand for oxygen in the water column, which is not environmentally desired. However, when 
evaluating at 3,14, 21 and 28 DAA (Table 5), it is seen that the spray volumes did not influence in the control of water hyacinth plants. The droplets classes did not interfere in the control from 3 DAA until 28 DAA. The application volumes and droplets classes provided control above $98.75 \%$ at 28 DAA.

Similarly, when low translocation herbicide is applied to plants, such as in the case of diquat, a difference is expected among the droplets classes (fine, extremely coarse and ultra coarse). However, in extremely coarse and ultra coarse droplets, besides presenting coverage (Table 3) and deposition (Table 4) enough for the control of target plants, there is no incidence of runoff to the application volumes used, seeing that the leaves and bulbs of $E$. crassipes are not water repellent to the used spray, as seen in tests previous to the application, through the analysis of a contact angle formed between the droplets and the surface of the target plant.

It is seen that the concentrations of the herbicide of 2 and $4 \mathrm{~g}$ of i.a. $\mathrm{L}^{-1}$, respectively, did not influence the uniformity coefficient (Table 6). The droplet classes presented differences among each other, in which fine, extremely coarse and ultra coarse droplets obtained values of 1.96, 1.6 and 1.4, respectively. Therefore, it is proven that ultra coarse droplets provide a better uniformity coefficient. It can also be noted that there was interaction among the concentration factors of the herbicide and droplets classes (DC) for the variable percentage of volume of droplets smaller than $100 \mu \mathrm{m}$.

It is seen that the extremely coarse and ultra coarse droplets classes associated to both concentrations of diquat in the spray were efficient in the reduction of potential drifting risk (\%Volume of Droplets $<100 \mu \mathrm{m}$ ) when compared to the fine DC in both concentrations of herbicide in the spray (Table 7 ), corroborating results obtained by Checheto et al. (2013) in wind tunnel.

The concentration of $4 \mathrm{~g}$ of i.a. $\mathrm{L}^{-1}$ when associated to fine DC (Table 7) obtained with the model TT 110015 (without air induction) altered the spectrum so that it would decrease the potential risk of drifting in this droplet class. This finding may be connected to the possible increase in the spray viscosity, provided by the greater concentration of the herbicide formulation in the spray (Oliveira et al., 2015). With that, there is an increase in the resistance to the elongation (elongational viscosity) and decreases the shear viscosity of the spray; with the alteration of these factors, there is generation of a droplet spectrum with a higher VMD (Table 1) and smaller percentage of the volume of fine droplets smaller than $100 \mu \mathrm{m}$ (Table 7) (McMullan, 2000).

Therefore, according to the parameters, it was concluded that the diquat herbicide can be applied with extremely coarse and ultra coarse droplets with a spray volume of $100 \mathrm{~L} \mathrm{ha}^{-1}$. These droplets classes provide greater potential safety in the application of the diquat herbicide in aquatic environment, associated with the deposition of the active and to sufficient coverage for the control of Eichhornia crassipes with both application volumes.

\section{LITERATURE CITED}

ALMEIDA, D. P. et al. Condições atmosféricas e volumes de aplicação na dessecação de Urochloa ruziziensis e vegetação espontânea. R. Bras. Herbic., v. 13, n. 3, p. 245-251, 2014.

ALMEIDA, D. P. et al. Droplets size categories and application volumes in burndown of plant covers. R. Bras. Herbic., v. 14, n. 1, p. 73-82, 2015.

AMERICAN SOCIETY OF AGRICULTURAL AND BIOLOGICAL ENGINEERS - ASABE. Spray nozzle classification by droplet spectra, ANSI/ASAE S572.1. St. Joseph, Michigan: 2009. 4 p.

BAUER, F. C.; RAETANO, C. G., PEREIRA F. A. R. Padrões de distribuição volumétrica de pontas de pulverização de jato plano 11002, com e sem indução de ar, sob diferentes espaçamentos e alturas. Eng. Agríc., v. 26, n. 2, p. 546-551, 2006.

BRACAMONTE, E. R. et al. Eficiência do herbicida sethoxydim em função do volume de calda no controle de papuã (Brachiaria plantaginea (Link.) Hitch.) na cultura da soja. R. Bras. Agroci., v. 5, n. 1, p. 60-63, 1999.

CHRISTOFOLETTI, J. C. Considerações sobre tecnologia de aplicação de defensivos agrícolas. Diadema: [s.n.], 1997. 12 p. (Apostila técnica da Spraying Systems do Brasil Ltda)

FOOD AND AGRICULTURE ORGANIZATION - FAO. Agricultural pesticide sprayers. Rome: 1998. v. 2. 62 p. 
FERNANDES, A. P. et al. Caracterização do perfil de deposição e do diâmetro de gotas e otimização do espaçamento entre bicos na barra de pulverização. Eng. Agríc., v. 27, n. 3, p. 728-733, 2007.

FERREIRA, M. C. et al. Distribuição volumétrica e diâmetro de gotas de pontas de pulverização de energia hidráulica para controle de corda-de-viola. Planta Daninha, v. 29, n. 3. p. $697-705,2011$.

GARCIA, L. C. et al. Dessecação da aveia-preta (Avena strigosa Schreb) com herbicida de contato, em presença ou não de assistência de ar junto à barra do pulverizador, em diferentes volumes de calda. Eng. Agríc., v. 24, n. 3, p. 758-763. 2004.

HOLM, L. B. et al. The world worst weeds: distribution and biology. Honolulu: University Press of Hawai, 1977. 609 p.

MARTINS, D. et al. Manejo químico de Eichhornia crassipes e Brachiaria subquadripara com diquat em condições de reservatório. Planta Daninha, v. 29, n. 1, p. 51-57, 2011.

MATUO, T. Fundamentos da tecnologia de aplicação de agrotóxicos. Jaboticabal: Funep, 1990. 139 p.

McMULLAN, P. M. Utility adjuvants. Weed Technol., v. 14, n. 4, p. 792-797, 2000.

OLALEYE, V. F.; AKINYEMIJU, O. A. Effect of a glyphosate (N-(Phosphonomethyl) glycine) application to control Eichhornia crassipes Mart. on fish composition and abundance in Abiala Creek, Niger Delta, Nigeria. J. Environ. Manag., v. 47, n. 2, p. 115-122, 1996.

OLALEYE, V. F.; AKINTUNDE, E. A.; AKINYEMIJU, O. A. Effect of herbicidal control of water hyacinth (Eichhornia crassipes Mart.) on fish composition and abundance in Kofawei Creek, Ondo State, Nigeria. J. Environ. Manag., v. 38, n. 1, p. 85-97, 1993.

OLIVEIRA, R. B.; ANTUNIASSI, U. R.; GANDOLFO, M. A. Spray adjuvant characteristics affecting agricultural spraying drift. Eng. Agr., v. 35, n. 1, p. 109, 2015.
OLIVEIRA, M. L.; MACHADO-NETO, J. G. Use of tracer in the determination of respiratory exposure and relative importance of exposure routes in safety of pesticide applicators in citrus orchards. Bull. Environ. Contam. Toxicol., v. 70, n. 3, p. 415-21, 2003.

PITELLI, R. A. et al. Doses e horário de aplicação do diquat no controle de Eichhornia crassipes. Planta Daninha, v. 29, n. 2, p. 269-277, 2011.

PITELLI, R. A.; MARTINS, D.; VELINI, E. D. Interferências e controle de macrófitas aquáticas. In: VARGAS, L.; ROMAN, E. S. Manual de manejo e controle de plantas daninhas. Passo Fundo: HRAC-BR, 2008. p. 299-328.

RODRIGUES, E. B.; ABI SAAB, O. J. G.; GANDOLFO, M. A. Cana-de-açúcar: Avaliação da taxa de aplicação e deposição do herbicida glifosato. R. Bras. Eng. Agr. Amb., v. 15, n. 1, p. 90-95, 2011.

SOCIEDADE BRASILEIRA DA CIÊNCIA DAS PLANTAS DANINHAS - SBCPD. Identificação e manejo de plantas daninhas resistentes aos herbicidas. Londrina: 2000. 32 p.

SOUZA, E. L. C. Impacto ambiental do uso do Glyphosate no controle de aguapé (Eichhornia crassipes). 201395 f. Thesis (Doctorate degree in Agricultural Engineering) Universidade Estadual de Campinas, Campinas-SP.

TIMOSSI, P. C. et al. Redução do volume de calda na dessecação de vegetação espontânea para plantio direto. In: SIMPÓSIO INTERNACIONAL DE TECNOLOGIA DE APLICAÇÃO, 6, 2013. Abstracts... Londrina: 2013. p 1-4.

TOMAZELA, M. S. et al. Avaliação da deposição da calda de pulverização em função da densidade populacional de Brachiaria plantaginea, do volume e do ângulo de aplicação. Planta Daninha, v. 24, n. 1, p. 183-189, 2006.

VOLPE, H. X. L. et al. Distribuição volumétrica de calda contendo Metarhizium anisopliae. Ci. Rural, v. 42, n.11, p. 1909-1915, 2012. 